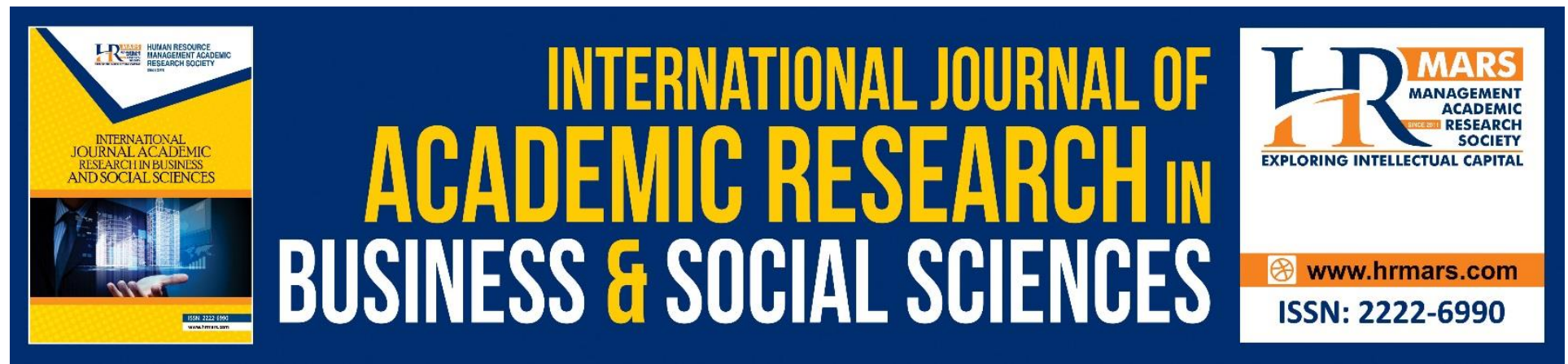

\title{
Empirical Research of European Funds Growth Share Absorption in the Field of Tourism Industry
}

\author{
Anamaria-Catalina Radu, Ivona Stoica, Ana-Maria Nedelcu, Andra-Luisa \\ Preda
}

To Link this Article: http://dx.doi.org/10.6007/IJARBSS/v11-i3/8921

DOI:10.6007/IJARBSS/v11-i3/8921

Received: 01 January 2021, Revised: 26 January 2021, Accepted: 15 February 2021

Published Online: 28 March 2021

In-Text Citation: (Radu et al., 2021)

To Cite this Article: Radu, A.-C., Stoica, I., Nedelcu, A.-M., \& Preda, A.-L. (2021). Empirical Research of European Funds Growth Share Absorption in the Field of Tourism Industry. International Journal of Academic Research in Business and Social Sciences, 11(3), 122-145.

Copyright: (C) 2021 The Author(s)

Published by Human Resource Management Academic Research Society (www.hrmars.com)

This article is published under the Creative Commons Attribution (CC BY 4.0) license. Anyone may reproduce, distribute, translate and create derivative works of this article (for both commercial and non-commercial purposes), subject to full attribution to the original publication and authors. The full terms of this license may be seen at: http://creativecommons.org/licences/by/4.0/legalcode

\section{Vol. 11, No. 3, 2021, Pg. 122 - 145}

Full Terms \& Conditions of access and use can be found at http://hrmars.com/index.php/pages/detail/publication-ethics 


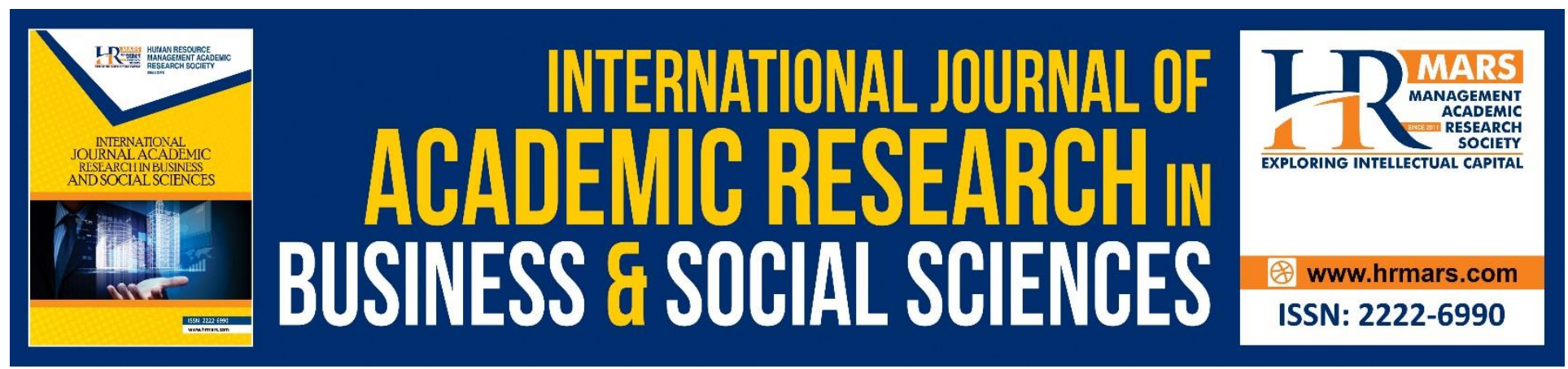

\title{
Empirical Research of European Funds Growth Share Absorption in the Field of Tourism Industry
}

\author{
Anamaria-Catalina Radu, PhD, Ivona Stoica, Ana-Maria Nedelcu \\ Romanian Academy, Institute of National Economy, Bucharest, Romania \\ Email: anamaria_radu15@yahoo.com, stradivonas@gmail.com, ana_maria_ned@yahoo.com
}

\author{
Andra-Luisa Preda, PhD \\ Romanian Academy, Bucharest, Romania \\ Email: luisapreda@yahoo.com
}

\begin{abstract}
The paper shows the evolution of the European funds' absorption share during the last years. We have applied a longitudinal research to study the perception regarding the European funds' absorption share in the field of the tourism industry and identify ways to improve it. A qualitative research has been established. We have analyzed the evolution of the absorption share of EU funds for Romania in comparison to other countries. As a final remark, the specialists agreed that within the growth of EU absorption the planning activities process is very important both for the organization as well as for the tourism industry, along with the marketing planning, which is another substantial subprocess for a successful strategy.
\end{abstract}

Keywords: EU Funds Absorption Share, Empirical Research, Planning Activities Process.

\section{Introduction}

The results obtained after the implementation of planning activities process within the organization depend to a large extent on the role the executive manager has in this process. In the specialists' opinion, he is the one that has to manage the defining of the organizations' work coordinates, take decisions in what regards strategic analysis, permanently study and maintain a balance degree between the results that can be obtained on the short and long terms, trust the planning process, have an entrepreneurial spirit to handle the bureaucratic system and make this dynamic at the planning activity level. (McDonald, 1998). Previously have been carried studies in the field of internal activities planning and marketing have shown that the organization leaders have a crucial role both in establishing a pleasant atmosphere at the enterprise level, as well as establishing the best relationships with employees (Wieseke, Ahearne, Lam, Van Dick, 2009, pp.123-145). The efficient implementation of the planning activities process depends to a large extent on the employees' qualities as well as their capacity of understanding the organization's vision and the objectives that are pursued. 
Various departments within the organization that deal with the management of strategic activity also have an important role in the planning activities process. Thus, in this structure the planning department has a crucial role. In order to obtain the best results at the organization level, the previously mentioned department has to permanently provide information about the structure and the planning systems that can be implemented within the enterprise, provide information of interest to the other departments, be solicitous to obtain the most recent data that help them predict different actions, be the connecting pivot between the research and development department and the one of marketing planning activities and planning process activities in order to gradually lead to the development of the organization, to evaluate the scheduled plans and analyze the way in which the approved plans evolve (McDonald, 1998). The studies conducted at the level of this domain have shown that the activity carried out within the marketing departments has the capacity to influence the company's marketing orientation (O'Sullivan \& Abela, 2007, pp.79-83). From this reason, specialists in planning should permanently analyze and observe the implications at the level of the activity carried out by the enterprise (Verhoef \& Leeflang, 2009).

The team that manages the planning activity within the company also has an important role in the planning activities process. This has the role of defining the strategies that have to be pursued both overall, as well as at the level of the enterprise's policies. The personal within the strategic department is the one that analyzes the external environment, the activity carried out at the industry's level, consumers as well as competitors. In addition, they have the designation to define the organization's objectives both on short term, as well as on long term and to define the elements of the marketing amalgam (Paley, 2000)

Paley (2000) mentioned that workers that deal with the making and implementing of the planning activities process within the organization should have the following responsibilities: to create and recommend new or additional products, to plan or to implement strategies during the products' life cycle, to develop programs and to improve the market place of the organization and its profitability, to identify the market opportunities and the changes that may occur at the consumers' demand level, to make the strategic planning activities. As we could observe, the human resource shows an increased importance, being the one that contributes to the good implementation of the actions within the organization. However, many times companies appeal to web technologies to streamline this process.

In the following part of the paper the way in which web technologies can be used within the planning activities process was analyzed. Planning activities process is a complex process that implies crossing several stages in order to accomplish the objectives within an organization. In order to facilitate its implementation at an enterprise's level, among time there have been a made a series of computer systems that use the data obtained from the audit to make predictions or give a series of information regarding the way in which the enterprise has to act in order to improve its activity. The intelligent computer systems have the designation to record the options of those from the organization and give suggestions regarding the way in which it should be acted at the market level. If we have to analyze planning activities process computer systems from the perspective of the way in which they are organized, it must be remembered that, in a primary step the users have to mention the strategic unit where the analysis takes place. Subsequent, the areas that show interest for managers have to be selected and make the audit and the SWOT analysis. Another important step for these programs regards the making of forecasts on the 
relations with the market. The underlying stage of all the above mentioned is the one in which objectives and strategies establishing are targeted by the organization. Thereby, in this stage the objectives and strategies that will be followed are established. All the planning activities process are based on a logical scheme, having the designation to analyze input data and offer a series of suggestions and recommendations based on those, keeping in mind the established objectives and strategies (McDonald, 1998). As we could observe from the previously mentioned, web technologies and instruments could facilitate the making the planning activities process and the marketing planning within the organization for the company's leadership. Thus, they can reduce the implementation time and can improve the results obtained.

\section{Methodology}

It is very important that all the stages specific to the research methodology to be completed in order for the results obtained from this research to be realistic and explain clearly the studied problem (Catoiu et al., 2009). We have conducted a qualitative research among the specialists in European funds in the tourism industry.

\section{Identifying the problem and defining the scope of the research}

During 2007- 2013 the field of accessing European funds in tourism had a sinusoidal development, characterized by the existence of several growth periods, stagnation and reduction of the absorption degree from the national level. In lots of cases it was noticed that the implemented projects didn't have a significant impact on the enhancement of the tourist activity at the destinations level. Previously conducted research showed that obtaining some important results after implementing projects financed from European tourism funds depend to a large extent on the way in which activities are organized and structured at the national level.

Taking into consideration that presently the beneficiaries have the possibility to access other projects through the new programs existing in the period 2014 - 2020, we considered conducting a qualitative research necessary, via which to identify the tourism experts' opinion regarding the way in which the planning activities process in general and the marketing planning process can be used in this field, both for facilitating the communication process between the beneficiaries and those within the Management Authority, as well as for highlighting the results obtained after these projects were developed.

\section{Establishing the objectives of the research}

Considering the decisional problem and the purpose of the previously presented qualitative research we have designed a few objectives. We have designed the primary objectives of this qualitative research such as:

- The perception regarding the evolution of the European funds accessing field in general.

- Accessing European funds in tourism field.

- The way in which the planning activity process can be applied in the domain of accessing European tourism funds.

- The importance of the planning activities process and the marketing planning in growing the share of EU funds absorption in the field on tourism. 
In what regards the way of data collecting, it has to be mentioned that the semi-structured indepth interview was used. According to the specialty literature (Catoiu et al, 2009) this is an indepth conversation, that is carried between an operator and an interviewed person with the purpose of obtaining some clear information regarding the inspected subject. A specific component of the semi-structured in-depth interview is the interview guide. This was made according to the previously mentioned objectives. The interview guide was divided into three major themes, that are: "Accessing European funds in general", "Accessing European funds in tourism" and "Applying planning activities process and marketing planning in the field of accessing European funds in tourism". The topics were presented since the beginning to each person individually in order for them to familiarize with the analyzed subject. The interview guide that was a tool to this research (Appendix 2). The length of making each semi-structured in-depth interview may vary between $30-45$ minutes.

\section{Target profile and the sample selection method}

In order to obtain very clear information regarding the analyzed subject, we reencountered 7 semi-structured in-depth interviews. The sample structure was divided into: four individuals that develop their activity within the National Authority for Tourism, a person that develops his activity within the Ministry of Economy (Tourism Department) and two individuals that run important tourism organizations: The Romanian Association of Balneology and the Tourism Marketing Organization in Romania. This balanced structure has helped us to obtain clear information regarding the scope of the research.

The participants' recruitment was made using a questionnaire containing 5 filter questions in order to select the individuals that were going to be interviewed for our qualitative research.

In order to record the data provided after the in-depth interviews, a recorder and a notebook to write the main ideas mentioned by the interviewees were used.

\section{Coordinates of the research}

This is a longitudinal study, because it has been repeated over the last four years, starting 2016. So, the same group was interviewed using the same variables in the period of February 2016- June 2019. This was a cohort study with low number of individuals and doesn't present difficulties in finding the selected individuals. After the interviews were made, the obtained data were processed, analyzed and interpreted.

\section{Discussion}

The qualitative study has the scope to identify the opinion of the specialists in tourism regarding the way in which the planning activities process and the marketing planning can be implemented in the domain of accessing European funds. As we previously mentioned, the study was applied on three categories: experts from the Ministry of Economy (Tourism Department), experts within the National Authority for Tourism and experts that presently run at least one important non-governmental association in the tourism field. The experts that took place at this study were coded in the following way: Expert 1, Expert 2, Expert 3, Expert 4, Expert 5, Expert 6 and Expert 7. At this study participated 7 individuals aged between $35-60$ years. The interviewees had as the last graduated school, bachelor's, master's or doctoral programme. The 
majority of the study participants have as passions tourism, travelling, martial arts, reading, philosophy, football, theatre, etc. The experts that participated in this study mentioned that they like to travel, both in the country as well as abroad. Some of them stated that they usually prefer the abroad destinations given to the offered services, while others claimed that they prefer the destinations inside the country. Expert 3 prefers to visit certain tourist destinations, both given to the attractions, as well as the possibility of practicing various sports. He prefers to spend his vacation, most of the times in the Apuseni Mountains, given to the diversity. Another specialist (Expert 1) mentioned that: "I prefer to travel, both within the country as well as abroad. If I have to travel within the country, I usually choose Caciulata, thanks to the balneary treatments and of the landscape. If I have to go abroad, I choose Greece, given to its sea, the services offered and the better conditions at the seaside." On the other hand, Expert 2 has stated that: "I usually like to travel, both within the country where most of the times I choose the mountain and submountain areas, as well as abroad". Expert 5 has mentioned that: "I like to travel both within the country as well as abroad. I usually travel to learn about different areas and to personally develop. I prefer destinations abroad, because I want to meet other cultures." On the other hand, Expert 6 considers the following: "I like to travel more within the country, as there are many areas that I have not visited yet, but I want to visit in the shortest time. (...) I prefer to visit any tourist destination that is not at the seaside." Expert 7 had a different opinion, mentioning that: "I like to travel both within the country as well as in the countries member of the European Union. I usually opt for the destinations in Romania, because I love my country."

In what regards the experts' opinion regarding the process of accessing European funds in general, the majority of the interviewees mentioned that it was made with difficulty. Some of them thought that the evolution was ascending, while others considered it was sinusoidal: "I consider that in this domain it could be more done that it was done effectively. Although, I consider that during 2007-2013 the evolution was ascending" (Expert 2); Expert 1 considered that the evolution was sinusoidal: "(...) if we have to analyze the evolution of this domain, we can say that it was difficult. Thus, the evolution was sinusoidal, at the level which increase and decrease periods were identified." Expert 3 had a similar opinion: "If we have to look overall at the evolution of this domain, we can mention that there were periods of increase, as well as of decrease, but these changes were irregular." Expert 4 had a different opinion, stating that: "(...) The opportunity of the European funds should be very attractive for Romania. I consider that the evolution, during this period of time, was ascending." Exert 5 has considered the following: "From my point of view, the evolution was ascending. Moreover, the European funds have brought a novelty degree in our country." Expert 6 has mentioned that: "From my point of view the evolution was ascending, however, influenced by a series of problems that occurred at the accessing process. Thus, the difficult money settlement has influenced many times the evolution of the accessing system." Expert 7 had almost the same opinion mentioning that: "I consider that the evolution was ascending until this year (2016), when I have encountered a blockage in accessing the European funds."

Regarding the role that the European funds financed projects have at the country level, it has to be mentioned that the interviewed experts totally agreed with the fact that these contribute to the economic development of the domains within they are implemented. One of the experts has detailed this subject mentioning that: "I consider that the European funds financed projects contribute to a large extent at the development of the main industries specific 
to Romania, especially is those are well drafted, and the aimed objectives are in agreement with the objectives from the national level " (Expert 1); Other experts have mentioned that they don't have detailed information regarding this subject, but in their opinion these had a very important role in developing the main industries of the country: "I don't possess detailed information regarding this subject. However, from what I've read I have understood that the results obtained had a strong impact on the developing of this sectors " (Expert 2); Expert 3 has affirmed that: "From my point of view, the most important role of the external sources financed projects is the financing. Thus, the beneficiaries weren't obliged to borrow from banks or to try to find other sources of financing to put their ideas into practice".

Expert 4 had another opinion, mentioning that: "The role of the projects financed from European funds was to contribute to the economic and social development of the country." On the other hand, Expert 5 has considered that: "The projects have contributed to a great extent to the development of our country. These have led to investments, the establishment of new jobs, the personal development of the employees, etc." Expert 6 has mentioned that: "Projects financed from European funds have the role of relieving the government of certain expenses. Thus, the money can be used in other areas of interest. In addition, through the projects financed from external sources, good access practices could be taken over from other countries, such as Poland. "

Looking at the extent to which these projects contributed to the development of the main industries of Romania, all the interviewed specialists mentioned that they had an important role in the development of these fields. Expert 1 mentioned that: "From my point of view the impact on the domains where the projects financed from European funds were implemented, was overwhelming." Expert 2 had the same opinion: "I consider that these projects have contributed to a great extent to the development of the main industries specific to Romania." Expert 7 had a different opinion: "I think that the projects financed from European funds don't contribute to the development of the main industries of Romania. Most of the times they are guided by some people to certain industries, development regions, etc." Analyzing from the domains' perspective, at the level of which most projects financed from European funds were submitted / accepted, the experts' opinions were divided. Thus, regarding the domains in which most projects were submitted, experts generally mentioned the educational or agricultural field. Analyzing in parallel, the domain within the fewest projects were submitted, is the transport infrastructure. According to the experts, most projects were accepted in the following fields: education, agriculture or tourism, while the sectors of activity that benefited from the lowest number of accepted projects are the infrastructure and transport. Expert 1 stated: "I believe that most projects have been accepted in education, tourism and agriculture. Instead, the fewest have been accepted in transport and infrastructure. In these areas we have not been able to meet our objectives. " Another expert apparently had the same opinion, considering the following (Expert 2): "Agriculture is one of the activity domains in which most of the projects financed from European funds were accessed. For example, in the wine subdomain the targeted objectives were fulfilled. On the other hand, the fewest were accessed in the infrastructure. " Expert 3 completed the previously presented, mentioning that: "From my point of view, the most projects were submitted in the field of education. The fewest ones were submitted in the field of research. If I have to analyze from the point of view of the domain where the most projects were accepted, respectively the fewest, I think most were concentrated in agriculture, while the least were in 
infrastructure or on the ecology side. " Expert 4 considered the following: "Most projects were submitted through POSDRU, and the fewest were on the infrastructure side." Expert 5 had the same opinion, mentioning that: "Most of the projects were submitted in the education and in the transport fields, while the fewest I consider that were submitted in medicine." Expert 6 stated that: "From my point of view, most projects have been submitted and accepted in agriculture. Many important investments have been made in this domain of activity. I think that the fewest have been registered in education." Expert 7 had another opinion: "I consider that most projects have been submitted and implemented in the field of tourism, while the fewest have been registered in the car construction industry."

Another objective of this research was to identify the evolution of the field of accessing European funds in tourism during the period 2007-2013. Most of the interviewees considered that the evolution was an ascending one, although there is the possibility of obtaining much results. better. Expert 1 mentioned that: "If we have to analyze the field of accessing European funds in tourism, overall, we can mention that it was quite good. Thus, $70 \%$ of the targets were reached. The evolution was ascending, because it was worked very hard in this area. " Another expert had another opinion (Expert 2): "I think that in the period 2007-2013, in the field of accessing European funds in tourism, it was achieved much less than it should have been and everything was done much worse than it could have. However, the growth was ascending. I believe that much more could have been done. " Expert 3 had a different opinion: "From my point of view, this evolution was prompt. There was only one accessing. We cannot discuss about a certain type of evolution." Expert 4 mentioned that: "Accessing European funds in tourism represented a real opportunity and lead to the development of several destinations. "Expert 5 considered the following: "From my point of view the evolution was an ascending one, over time being accessed an increasing number of projects financed from European funds." Expert 6 also had the same opinion, stating that: "I consider the evolution to be an ascending one, even though we have only been able to access half of what we set out to do." Expert 7 had the same opinion: "From my point of view, the evolution of the field of accessing European funds in tourism has been slightly ascending."

Regarding the way in which tourism would have evolved in the absence of the possibility of accessing European funds in this domain, the opinions were divided. Thus, some experts considered that the evolution of tourism would be the same, the results obtained being lower, while some of them considered that the influence of these European funds was not significant during this period. Expert 1 mentioned that: "It is possible that, if the European funds for tourism did not exist, the evolution of this field would not have been as good. However, I believe that tourism would have had an ascending growth even without these investments. " On the other hand, Expert 2 was, in part, of the same opinion arguing that: "I consider that tourism would have evolved clearly in the same direction, but with much lower profits. Thus, if there had not been such projects financed from European funds, a large part of those who accessed in this period would not have made such investments. That's why I think they were a win for the tourism field. " Expert 3 stated the following: "From my point of view, the evolution would have been the same. The beneficiaries would probably have been helped by other means, different from the field of accessing the European funds in tourism." Expert 4 had another opinion, mentioning that: "Without European funds, tourism would have experienced an involution, as has happened with other economic sectors." Expert 5 considered something else: "From my point of view the 
evolution would have been the same, although the impact would not have been as great." Expert 6 had the same opinion, mentioning that: "I think the evolution would have been the same, but the results would not have been as important. We have to take into account that money has entered the economy, which have been used in various domains of activity. Their absence would have prevented the investments carried out until this period. "Expert 7 had another opinion: "Tourism would have evolved in the same direction. I think that in some cases, people did not even realize how much money they had accessed for various projects."

Regarding the opinion of the experts on the development regions, in which the most projects financed from European tourism funds were accessed, some of them mentioned Transylvania. Although it is not a development region, they considered that most projects financed from European funds in tourism were oriented towards this area. In addition, as regards the development regions to which the fewest projects financed from European funds were distributed, their views were divided. Thus, although most of the experts mentioned that they do not have detailed information on this subject, some considered the North-East development region, while others opted for the South-East region. "I don't have many details on this subject, but from my point of view the most were oriented, especially towards the part of Transylvania, while the fewest were oriented towards the area of Moldova, in the North-Eastern part of the country "(Expert 1); Expert 2 had almost the same opinion: "From my point of view, most projects financed from European tourism funds were oriented towards the Transylvania area, while the fewest were oriented towards the South-Eastern region of the country.. " Expert 3 considered the following: "I think most have been directed to the Center region and to the North-Western region. If it is to analyze from this point of view, I consider that the fewest projects financed from European funds in tourism have been allocated to the North Eastern region. " Expert 4 did not have specific information on this topic, mentioning: "The Center region has benefited from the most numerous projects so far. I do not have information about the regions where the fewest projects were implemented, so I cannot express my opinion on this subject. "

Expert 5 mentioned the following: "From my point of view, the development regions, at which the most projects financed from European funds in tourism were implemented were: the Center Region, North Eastern Region and North Western Region. I think the fewest have been implemented at the level of the South-Eastern Region and at the level of the South-Muntenia Region. " Expert 6 had another opinion: "I consider that the most projects were submitted and accessed in the Center region. In this region the European funds allocated for tourism were exhausted. The fewest projects were accessed in the South- West Oltenia region, as well as in the North-Eastern region. " Expert 7 had the same opinion: "Most of the projects were oriented towards the Center Region, while the fewest were oriented towards the South-West Oltenia Region."

Another objective of this research was to identify the development regions, towards which the projects financed from European tourism funds should have been oriented. Thus, most of the interviewees mentioned that they should have been distributed differently at the level of each development region depending on the needs existing within them. Some experts considered that they should have been oriented towards the Northern regions, while others thought that they should have been planned at the country level, except in Bucharest. "I think that if we have to analyze from the perspective of the infrastructure, to reach as much as possible the areas with tourism potential, more European funds should have been allocated in the 
Northern region of the country" (Expert 1). Another expert (Expert 2) mentioned that: "I think that the European tourism funds should have been allocated at the level of the whole country, except in Bucharest. They should have been implemented in the areas with a high tourism potential. That's why I made this choice. " Expert 3 had another opinion: "I think that the most of these projects should have been oriented towards the South-East of the country. Towards the coast and towards the Danube Delta." Expert 4 considered the following: "To the areas where they were not accessed many projects. "; "From my point of view, these projects should have been directed to those areas where a high number of projects were not implemented, more precisely in the South and South-East of the country" (Expert 5); Expert 6 had same opinion, mentioning that: "I think that the projects financed from European funds should have been oriented towards the areas where a limited number of investments were made, for example towards the South - West part of the country or towards the North - East."; "From my point of view, the projects financed from European funds, should have been oriented towards the development regions where there are mineral water resources." (Expert 7)

Analyzing from the perspective of the components of the tourism product to which most of the projects financed from European funds should have been concentrated, it should be mentioned that almost all those who participated in the study, declared that they focused mainly on accommodation. One of them considered that this is not a favorable aspect. If it is to analyze from the perspective of the forms of tourism, to which the majority of the projects financed from European funds in tourism were oriented, a great part of the experts mentioned the balneary tourism. Expert 1 considered the following: "Most projects have been allocated to the balneary tourism side in order to improve the treatment bases at the destination level." Expert 2 had the following opinion: "From my point of view, most projects were allocated to improve the tourist activity at the level of the balneary resorts." Expert 3 was of the same opinion: "I consider that most projects financed from European funds in tourism were implemented on the part of the accommodation units. Analyzing from the perspective of the forms of tourism, most were oriented towards the balneary tourism." Expert 4 mentioned the following: "Most of the projects funded from European funds have been used to improve accommodation. The main form of beneficiary tourism was mountain tourism." Expert 5 considered that: "From my point of view, most projects financed from European tourism funds have sought to create new accommodation units or to improve the existing ones. Looking at the form of tourism, most have focused on balneary tourism. "Expert 6 was of the same opinion, mentioning: "I consider that most projects financed from European funds in tourism were aimed at the establishment of accommodation units in the areas where the balneary tourism can be practiced." ; "Most projects financed from European funds have targeted accommodation units in mountain areas." (Expert 7)

Another objective of this qualitative research was to identify the main strengths, weaknesses and barriers in accessing European funds in tourism. If we look at the main strengths, the opinions of the experts have been divided. Some of them mentioned that the projects contributed to the improvement of the promotional activity: "These European funds allocated in the field of tourism were very good, because they contributed to the improvement of the promotional activity at the level of the development regions. In addition, they helped to implement some models of good practices "(Expert 1), while others considered that they were beneficial, as they allowed the restoration of some important monuments:" From my point of view, these projects financed by European funds in tourism were especially favorable due to the 
fact that they allowed the financing of monuments of direct importance in the development of tourist destinations in different areas "(Expert 2); Expert 3 mentioned the following: "From my point of view, the most important strengths of these projects financed by European tourism funds, refer to the fact that they contribute to the improvement of the tourist activity at the destination level, as well as to the development of the society as a whole. . "; "I think the most important strength is the availability of European funds" (Expert 4); Expert 5 was of another opinion, mentioning: "From my point of view, the most important strengths are: the possibility of creating and equipping different tourist information centers and the possibility of promoting the tourism potential at the level of each development region. " Expert 6 stated that: "I think the main strength is the easy process of accessing and implementing projects financed from European funds." Expert 7 mentioned: "Projects financed from European tourism funds have led to an increase in the number of tourists, an increase in the number of jobs in the areas where they have been implemented, as well as an increase in consumption."

If it is to analyze from the point of view of weaknesses, we can mention that the opinions of the experts have been divided. Some of them considered that excessive bureaucracy or inflexibility were the main weaknesses of these projects financed by European tourism funds, while others considered that the allocation of resources to certain inefficient projects is the most important weakness. Expert 3 stated: "I think one of the most important weaknesses refers to the fact that these projects have not been oriented enough towards the development of the recreation." Expert 4 considered: "The main weaknesses are: excessive bureaucracy and numerous authorizations." "From my point of view the weak points refer to the lack of experience and knowledge from the beneficiaries." (Expert 5); "I believe that the main weaknesses are the poor settlement and the difficult monitoring of the projects by those within the Managing Authority." (Expert 6); Expert 7 had another opinion, stating: "From my point of view, the use of poorly prepared workforce is the most important weakness."

The main barriers identified by the experts having the ability to prevent the absorption of European funds at national level were the inefficient communication system between the parties, the law of public acquisition, the excessive bureaucracy, etc. Expert 1 considered that "the legislation, in general, can be seen as one of the most important barriers, having the capacity to prevent the absorption of European funds: In addition, public acquisition law is another issue in this area. " Another specialist (Expert 2) mentioned: "The system of relationship between the partners is the one that affects the absorption process of the European funds to the greatest extent." Expert 3 was of another opinion: "From my point of view, the way of carrying out the financing process is one of the most important barriers in this field." Expert 4 considered the following: "The main barriers are, limiting the types of beneficiaries who can access various European funds, as well as the weight of the access process." "From my point of view, I consider that the main barriers refer to: the lack of personnel and an experienced management team" (Expert 5); "I believe that the main barrier to accessing and implementing projects funded from European funds in tourism is excessive bureaucracy" (Expert 6); "The strongest barrier is excessive bureaucracy at both the European Commission and the country level." (Expert 7)

Analyzing from the perspective of the impact, which most of the projects financed from European funds had at the level of the development regions where they were implemented, all the experts participating in the study agreed that these projects contributed to their economic development, contributing to improving tourism in the area. Regarding the main modalities, 
through which the beneficiaries can improve the results obtained from the development of such projects, the experts mentioned that they have the possibility, either to implement other projects or to benefit from external support. Expert 3 mentioned: "I believe that these projects had a strong impact at the level of the development regions where they were implemented. They have contributed to a great extent to the increase of the tourist circulation, to the increase of the notoriety or to the development on the cross. To improve the results. the beneficiaries should have a strategic thinking permanently aimed at identifying and implementing continuous investments. " Expert 4 had the following opinion: "From my point of view, these projects financed from European funds have contributed to the exploitation of Romania's tourism potential. In the next period, the potential beneficiaries should be oriented towards other financing opportunities." "I consider that the impact was very high. Thus, in the regions that had a high degree of development (Center and North - West), the projects financed from European funds contributed to the development of the tourist activity, while at the level of the development regions. New information centers and new jobs have been created in the South and South-East of the country. As regards the main ways of improvement, I believe that partnerships with various economic agents from the development regions should be concluded. "(Expert 5); "From my point of view, the projects financed by European funds in tourism have led to the increase of the visibility of Romania, through the promotional actions that have been carried out and have increased the importance of certain tourism products" (Expert 6); "The impact has been positive, contributing both to the development of human resources and to the development of certain areas." (Expert 7)

Another objective of this study was to identify the opinion of the experts on the sustainability period of the projects financed from European tourism funds. They considered that the objectives set during this period are relevant. In addition, the stage is particularly beneficial for large projects, whose results can be highlighted during this period. Looking at the frequency with which the objectives of the sustainability period should be analyzed, most experts considered that they should be evaluated annually. Expert 3 considered the following: "The objectives of the sustainability period are not very relevant. There should be a review of them. The evaluation of how they were implemented should be checked once a maximum of 3 months." "From my point of view, the optimum sustainability period is 3-5 years." (Expert 4); "During the sustainability period, the experts are obliged to support the promotion activity from their own sources. I believe that the objectives have been set correctly and evaluated from the moment of the implementation of the project. " (Expert 5); "From my point of view the sustainability period is set correctly. The evaluation should be done annually." (Expert 6); "I think the sustainability period is a good one to check the evolution of the projects. The evaluation should be done annually." (Expert 7)

Another objective of the study was to identify how the planning activities process in general and the marketing planning process in particular can be implemented in the field of accessing European tourism funds. Thus, all experts agreed that it is necessary to implement the planning activities process in this field they considered that market studies should be conducted to illustrate the situation existing at the level of different tourist destinations. Expert 2 stated: "Different studies should be carried out to illustrate what is actually happening in the territory. Through these analyzes will identify the forms of tourism or the tourist destinations to which the European funds in tourism should be allocated." Another specialist was also of the opinion: "The 
planning activities process and the marketing planning should be used in the field of accessing the European funds in tourism. Thus, all the existing tools in the specialized literature should be used. In addition, market studies should be developed to observe what is actually happening at the level of tourist destinations. " (Expert 1); Expert 3 had the following opinion: "The planning activities process and the marketing planning is important in any field, and especially in the field of accessing European funds in tourism. This is very important in planning the activity in this area, in promoting the activities developed, improving the communication process. etc. Moreover, this can also help the beneficiaries to highlight the results they have achieved, using the marketing techniques and tools, they can identify the level of consumer satisfaction, the perception of the quality of the products or services., as well as how they can improve their service. "

"Planning activities and marketing planning process can be successfully integrated in the field of accessing European funds. I believe that it can be integrated by introducing into the project, in the phase of elaborating an evidence for using the planning activities process and the marketing planning." (Expert 4); "It is very important to apply it in the field of accessing the European funds in tourism. I believe this can improve the activity of promotion, that of the planning events, etc." (Expert 5); "From my point of view, I think applying it in this area is very important. This can help to improve the process of promoting the beneficiary's guide." (Expert 6); "I believe that the planning activities process and the marketing planning can be implemented in the field of accessing European funds in tourism by taking into account the marketing elements when drafting European projects." (Expert 7)

Analyzing from the perspective of how marketing can leverage the results obtained from the implementation of projects funded from European tourism funds, the experts considered that marketing techniques and tools can help the beneficiaries to carry out market studies, to realize their own promotional campaigns, to make various marketing plans and planning activities programs, etc. Expert 1 mentioned: "The beneficiaries should permanently carry out marketing activities, conducting market studies to better understand what their customers want, identifying their satisfaction so that afterwards they can see how they can improve it." Expert 2 completed the above: "The beneficiaries should use the planning activities process and the marketing planning to develop the marketing plan and programme at their organization level."

"The planning activities process and the marketing planning can support the promotion of tourism products or categories of tourism, it can lead to the increase of the tourist circulation, to the creation of partnerships." (Expert 5); "The planning activities process and the marketing planning can improve the activity of the beneficiaries and can increase the number of tourists." (Expert 6); "I believe these can help the beneficiaries in analyzing the market, in developing new products and to establish prices." (Expert 7)

Another objective of the research was to identify the main advantages that can be obtained from the implementation of the planning activities process and the marketing planning in the field of accessing European funds in tourism. Most experts considered that this would contribute to improving the absorption rate and to the efficient distribution of projects funded from European funds. In addition, the experts unanimously agreed that the use of planning activities and the marketing planning in the field of accessing European tourism funds does not bring any disadvantage in this area. Expert 1 mentioned: "The use of the concept of marketing in the field of accessing European funds in tourism can bring a number of benefits. I think the most important thing is that it can contribute to increasing the absorption level at national level." On 
the other hand, Expert 2 considered: "From my point of view the implementation of the planning activities process and the marketing planning in this field is important, because it allows an efficient allocation of the projects financed from external funds. I do not think there are disadvantages in this case." Expert 3 had the following opinion: "I do not consider that there are disadvantages in the implementation of the planning activities process and the marketing planning in the field of accessing European funds in tourism. From my point of view the main advantages are the identification of the existing situation, the audit of the destination and the possibility of improving the communication process." "The use of marketing planning in this area will automatically lead to both the development of the project funded from European funds and the development of the business that was created." (Expert 4); "I consider that the main advantage is that through the planning activities process and the marketing planning the results obtained from the implementation of the projects financed from European funds can be emphasized." (Expert 5); "The main advantage of marketing integration, at this level, is that it, through its actions, can increase the visibility of tourist destinations." (Expert 6); "I believe that these projects funded from European funds can contribute to improving the results obtained by the economic agents at the level of the development regions." (Expert 7)

Analyzing from the perspective of the advantages that the communication activity can offer in the existing relationship between the Managing Authority - Beneficiaries - Clients, it should be mentioned that most experts agreed that it has the capacity to improve the existing contacts between these parties. One of the experts was of the opinion that it contributes to a great extent to the improvement of the relations and to the facilitation of the transmission and reception of the information. Another objective of the research was to identify how the planning activities process in general and marketing planning in particular can be implemented in the field of accessing European tourism funds. Thus, looking at the marketing planning section of the Master Plan, all the experts who participated in the study agreed that this should be improved, by adding certain structures and by conducting new market studies. Expert 2 said: "I think the existing marketing section in the Master Plan should be improved. Some sections should be added, while some should be updated. Moreover, I think other market studies would be important. " Expert 1 had the same opinion: "I think that the marketing section of the Master Plan should be improved and some information updated, which is currently found in this document, should be updated." "I believe that this strategic document should be updated by implementing at its level a realistic marketing plan with clear objectives." (Expert 3); "Updating the marketing section of the existing Master Plan is required at a certain time." (Expert 4); "From my point of view, the marketing section currently existing in the Master Plan is quite well implemented, but I do not know if it is applicable in our country from the legislative and budgetary point of view." (Expert 5); "From my point of view, the Master Plan is an important document, but it is not taken into account. Nobody analyzes what is written in it because each person has their own vision which they consider to be more important." (Expert 6); "The age of the Master Plan suggests that it should be revised. It should be updated by tourism marketing specialists." (Expert 7)

Regarding the opinion of the respondents regarding the possibility of integrating in this document a section on the marketing planning of the European tourism funds, all the experts who participated in the study mentioned that this proposal is a favorable one. Thus, this would facilitate access to European funds and would greatly help those who wish to implement such 
projects at the destination level. Expert 1 mentioned: "It is very important to have such a section in the Master Plan. This would be beneficial for both the state institutions and the beneficiaries. However, the realization of such a section implies carrying out detailed studies, which means a pretty high effort. " Expert 2 had the same opinion: "Such a section would be very good at the Master Plan level. I think this is very important and would greatly improve the activity carried out in this area." "From my point of view such a section would improve the degree of absorption as well as the tourist activity at the destination level." (Expert 3); "There is a need for a correlation between the planning of accessing European funds and the national objectives of tourism." (Expert 4); "From my point of view, the introduction of such a section at the Master Plan level would bring added value to the beneficiaries because it would lead to a much easier information." (Expert 5); "I believe that the implementation of such a section is not important because the information contained in the Master Plan is not based on the decisions taken by the beneficiaries or by other important institutions" (Expert 6); "I consider it absolutely necessary to implement such a section at the Master Plan level" (Expert 7).

Another objective of this qualitative research was to identify the way in which web tools and technologies can be implemented in the field of accessing European tourism funds. All the participants who participated in the study were of the opinion that these tools have the capacity to facilitate the communication process due to the interactivity of the messages, the images that can be transmitted, etc. Expert 1 mentioned: "Web tools are very important in the field of accessing European funds in tourism, facilitating the transmission of information. In addition, communication is made much easier through them." Expert 2 had the following opinion: "Web tools are important in this field, because, through them, the information can be transmitted in a special, interactive format, which will attract the receivers."; "Web tools are very important, they facilitate the transmission and reception of information" (Expert 6); "Web tools allow access to information in real time." (Expert 7).

Regarding the perception of the experts, regarding the main sources of information currently used by the potential beneficiaries to document on the existing financing opportunities, most mentioned the websites and the portals specially destined to this field. "From my point of view, I believe that the website is the most used online tool by the potential beneficiaries to document on the existing opportunities at the destination level. Moreover, the websites of the regional development agencies are also a source. important information. " (Expert 1); "From my point of view, I believe that websites, specialized portals and e-mail are the most important tools that are currently being used by beneficiaries to document with regard to existing financing opportunities." (Expert 2); Experts 3 and 4 considered that the most important online sources used by the beneficiaries to document the opportunities on the market are the websites, the specialized portals, etc. Expert 5 stated the following: "From my point of view, the tool most used by beneficiaries at this time is the website. This is the one that facilitates the transmission of information."; "At this moment the most used tool is the website of the responsible institutions. Therefore, I think that it should be permanently updated, easy to use and clearly explain the steps that must be taken by the beneficiaries." (Expert 6); Expert 7 considered the following: "I think the website is the most used online tool at the moment. "

Analyzing from the perspective of the online communication sources used to communicate the results obtained from the projects financed from European funds, most experts mentioned that the most used means are their own websites, as well as the different web portals. 
In addition, social media as well as e-mail marketing are other tools commonly used by beneficiaries to enhance their results. "In my opinion, the beneficiaries most often turn to websites and social media to communicate the results they have obtained following the development of projects financed from external funds." (Expert 1); On the other hand, Expert 2 considered that e-mail and websites are the most widely used means, allowing instant information to be sent to a diverse audience. much accessing and running projects funded from European tourism funds. The main sources used by the beneficiaries to document on the opportunities existing on the market are the websites and specialized portals, which are the most visited. On the other hand, the beneficiaries most often turn to websites, social networks and specialized portals to communicate with their clients and to attract them.;" The most important sources of online information are the websites, for example the site fonduri-ue.ro. The main sources of online communication I think are the web pages of the projects. "(Expert 4);" I think that the whole web site is the most used by the beneficiaries. Nowadays this is the most widespread and people tend to access websites when they need certain information. "(Expert 5);" From my point of view, the beneficiaries most often use the websites, this being the information medium used most often by the companies."(Expert 6);"I think the beneficiaries call the most frequently on websites, portals, forums, etc. "(Expert 7).

\section{Analysis of the European funds' absorption share evolution}

Besides the qualitative research, we also analyzed the real situation based on EUROSTAT data in which regards the EU Cohesion Policy. The data collected for European Union Cohesion Policy analysis concerning the absorption share, is composed of European Regional Development Fund, Cohesion Fund, European Social Fund, including European Territorial Cooperation.

In this analysis, the data collected refers to the annual payments (not cumulative) made by the Commission from the EU budget to each Member States broken down by Fund and by year so all the expenditure are very well structured. In this analysis, it has been also taken into account the totals paid by year (across funds) provided by the EU Member States, it shows the payments made during each year broken down by interim payments and pre-financing. The absorption EU share (\%) and the percent paid to each Member state is shown in the tables compared to total available budget.

Based on the data presented below we made a comparative analysis at the level of six European Union Member states from the perspective of the percent paid to each Member state compared to the total available budget registered in the period 2007 - 2016. For this analysis we have chosen the following Member states: Romania, Bulgaria, Greece, Hungary, Germany and France. In addition, we have analyzed the two previously mentioned indicators at the level of all the European Union Member states. In 2007, the total payments for Romania were $417,022,849.39$ euro, from which, 73,682,952 euro were used for the projects within the European Social Fund (ESF). 179,529,321.31 Euro were allocated for the European Regional Development Fund (ERDF) and 163,810,575.71 Euro for the Cohesion Fund (CF).

In 2008 Romania has registered an increase of $53.93 \%$ compared to the previous year of

these payments made by the European Commission towards our country, while in 2009, there was a slight increase, of only $41.63 \%$ (compared to 2008), reaching at 909,124,666.96 Euro. In 2010 there were $44.37 \%$ less allocated amounts compared to the previous year, their total being of 505,729,070.16 Euro, from which most was allocated towards the projects financed from the 
Cohesion Fund $(175,172,828.47$ Euro) and in the ones of European Social Fund $(171,282,418.31$ Euro). Towards the projects within the European Regional Development Fund the amount of 159,273,823.38 Euro has been paid. Starting from 2011 and until 2014 there have been progressive increases registered, in 2014 the total amount granted for Romania being of 3,536,806,630.61 Euro (+22.62\% compared to 2013). In 2015 towards our country there have been funds with $26.73 \%$ less compared to the previous year, the total amount reaching at 2,591,361,157.7 Euro, from which the most part has been granted towards the projects made within the ERDF $(952,048,770.01$ Euro) and 905,647,284.61 Euro towards the ones within the Cohesion Fund. Towards the projects within the European Social Fund the European Commission has paid 733,665,103.08 Euro. The year 2016 was favorable for our country, the total value of the influx from the European Commission being 3,663,963,114.63 Euro, with $41.39 \%$ more compared to the previous year. If we have to analyze from the absorption's perspective (show the \% paid to each Member state compared to total available budget.) it can be noticed that in 2007 (the value reached was 2.2\%) progressive increases have been registered, in 2016, this reaching the value of $90.49 \%$.

If we have to study Bulgaria's situation it can be observed that the payments made in 2007 by the European Commission from the European Union's budget were of $144,887,745.71$ Euro, the most part being towards the projects included in the ERDF (64,102,644.32 Euro). Towards the ones from the CF the amount of 57,075,904.13 Euro was allocated, and for the ones from the ESF, Bulgaria has received 23,709,197.26 Euro. In 2008, Bulgaria has received with $53.94 \%$ more wages compared to the previous year, however, these decreasing with $19.69 \%$ in 2009. The highest amount paid by the European Commission to Bulgaria was registered in 2012, when the total values registered wee with $56.41 \%$ higher than the previous year, reaching at $843,560,545.92$ Euro. Lately, the growths were slower, in 2016 taking place a decrease of $48.64 \%$ of these values. The amount sent to Bulgaria in 2016 was of 643,932,096.11 Euro, from which the most part has been allocated to the projects financed via CF $(330,874,028.01$ euro) and $306,994,494.54$ Euro were sent to the ERDF. The smallest part has been distributed for the projects included in ESF $(6,063,573.56$ euro). Regarding the absorption level, it has progressively grown, in 2016 reaching at $97.33 \%$.

Another country under analysis in this paper was Greece. In 2007, the European Commission paid 401,029,220.84 Euro to this country, of which 242,986,003.56 Euro to projects financed by ERDF and $84,100,000$ Euro to ESF projects. The lowest amount was sent to the CF 73,943,217.28 Euro. Between 2008 and 2010 there were increases in the level of payments made by the European Commission to this country. Thus, in 2010 the total payments were $2,270,840,607.59$ Euro (+98.47\% compared to 2009), of which the largest volume was allocated for projects financed from ERDF - 1,718,258,112.20 Euro. Lower values were allocated to those in the ESF - 292,445,396.70 Euro and to those in the CF - 260,137,098.69 Euro. Between 2011 and 2012, the increases were not so high, in 2013 they were $42.34 \%$ higher than the previous year, reaching 4,111,843,859.09 Euro. Between 2014 and 2016, the payments made by the European Commission from the EU budget to Greece started to fall, reaching in 2016 to $386,660,271.54$ Euro (-80.49\% compared to 2015$)$.

Table 1. Share of European funds absorption show the \% paid to each Member state compared to total available budget 
INTERNATIONAL JOURNAL OF ACADEMIC RESEARCH IN BUSINESS AND SOCIAL SCIENCES Vol. 11, No. 3, 2021, E-ISSN: $2222-6990$ @ 2021 HRMARS

\begin{tabular}{|l|l|l|l|l|l|l|}
\cline { 2 - 7 } \multicolumn{1}{c|}{} & Romania & Bulgaria & Greece & Hungary & Germany & France \\
\hline $\mathbf{2 0 0 7}$ & $2.22 \%$ & $2.20 \%$ & $1.98 \%$ & $2.17 \%$ & $2.00 \%$ & $1.56 \%$ \\
\hline $\mathbf{2 0 0 8}$ & $5.64 \%$ & $5.58 \%$ & $4.96 \%$ & $5.56 \%$ & $5.23 \%$ & $4.96 \%$ \\
\hline $\mathbf{2 0 0 9}$ & $10.48 \%$ & $9.63 \%$ & $10.62 \%$ & $13.05 \%$ & $17.46 \%$ & $13.59 \%$ \\
\hline $\mathbf{2 0 1 0}$ & $13.17 \%$ & $15.65 \%$ & $21.86 \%$ & $21.02 \%$ & $28.63 \%$ & $23.61 \%$ \\
\hline $\mathbf{2 0 1 1}$ & $16.89 \%$ & $23.83 \%$ & $34.94 \%$ & $35.04 \%$ & $41.20 \%$ & $34.53 \%$ \\
\hline $\mathbf{2 0 1 2}$ & $22.95 \%$ & $36.62 \%$ & $49.23 \%$ & $43.93 \%$ & $54.13 \%$ & $43.01 \%$ \\
\hline $\mathbf{2 0 1 3}$ & $38.31 \%$ & $50.05 \%$ & $69.58 \%$ & $59.01 \%$ & $70.82 \%$ & $59.95 \%$ \\
\hline $\mathbf{2 0 1 4}$ & $57.14 \%$ & $66.23 \%$ & $88.28 \%$ & $76.11 \%$ & $83.32 \%$ & $76.27 \%$ \\
\hline $\mathbf{2 0 1 5}$ & $70.93 \%$ & $85.24 \%$ & $98.09 \%$ & $88.37 \%$ & $92.47 \%$ & $92.12 \%$ \\
\hline $\mathbf{2 0 1 6}$ & $90.49 \%$ & $97.33 \%$ & $100.00 \%$ & $99.64 \%$ & $97.60 \%$ & $99.58 \%$ \\
\hline
\end{tabular}

Source: Author's documentation based on the EUROSTAT data

Regarding how this amount was broken down, it should be noted that, 217,228,289.99 Euro were allocated for the projects financed from ESF, 127,063,506.01 Euro to those from ERDF and $42,368,475.54$ Euro to CF ones. Analyzing from the perspective of the degree of absorption, if in 2007 it was $1.98 \%$, in 2013 it was $69.58 \%$ and in 2016 it reached $100 \%$. Hungary is another country that has undergone this analysis. It is noted that the amounts allocated by the European Commission in 2007 were higher compared to the other countries analyzed previously, reaching $533,756,229.67$ Euro. In 2009, the increase was $121.03 \%$ compared to the previous year, reaching $1,839,652,587.88$ Euro, out of which, most of it was allocated to projects financed from ERDF $1,029,409,537.08$ Euro. Lower values were allocated to those from CF - 551.486.635.86 euro and to those from ESF - 258.756.414.94 euro. Another important increase was recorded in 2011 (+ $75.82 \%$ compared to the previous year), the total amount of payments made by the European Commission for this country being 3,443,346,889.70 Euro. Decreases in these values were recorded in 2012 (-36.6\% compared to the previous year) and in 2015 (-28.36\% compared to 2014).

In 2016, the total amount allocated for Hungary was 1,390,975,454.79 Euro $(-53.79 \%$ compared to 2015). And then, the highest amount was allocated to the projects financed through $\operatorname{ERDF}(733,557,245.99$ euro) and those from $\operatorname{ESF}(489,596,665.05$ euro). For the CF, the total value was $167,821,543.75$ Euro. The degree of absorption also increased progressively, from $2.17 \%$ in 2007, to 43.93 in 2012 and to $99.64 \%$ in 2016. In Germany, the payments made by the European Commission from the budget of the European Union in 2007 amounted to 509,772.325.80 Euro, reaching in 2009 at 3,112,147,884.82 Euro (+278.54\% compared to 2008). In 2010 there was a decrease with $8.57 \%$ of these amounts, followed by increases of $2.87 \%$ and $29.13 \%$ in the following period. In 2016 there was a decrease of payments by $76.51 \%$, their value being $547,207,419.14$ Euro. Of this amount, 383,090,876.23 Euro were allocated for projects financed from ERDF and 164,116,542.91 Euro to those from ESF. Regarding the absorption of these funds, there were progressive increases, from $2 \%$ in 2007, to $54.13 \%$ in 2012 and to $97.6 \%$ in 2016.

In France, in 2007, the amounts received from the European Commission amounted to $211,145,914.74$ Euro, of which, for the projects developed at ERDF level, it was 105,212,139.56 Euro and for those from ESF 105,933,775.18 Euro. In 2008, there was an increase of $118.48 \%$ compared to the previous year, the total payments to this country being of $461,315,137.81$ Euro. 
Significant growth was recorded in 2009 (+ 153.34\% compared to 2008 - reaching 1,168,711,281.86 Euro) and in 2013 (+99.59\% compared to 2012, reaching 2,294,477,514.81 Euro). In 2013, the amount allocated was divided as follows: 1,317,737,650.74 Euro to projects financed from ERDF and 976,739,864.07 Euro to those from ESF. Between 2014 and 2016, the amounts paid by the European Commission to France began to decrease, in 2016 they accumulated a total of 389,799,714.21 Euro, out of which 264,253,600.55 Euro were granted for projects from ERDF and 125,546,113.66 Euro to those from ESF. Regarding the degree of absorption (\% paid to each Member state compared to total available budget), it increased from $1.56 \%$ in 2007 , to $76.27 \%$ in 2014 and reached in 2016 at $99.58 \%$.

If we are to carry out this analysis at EU 28 level between 2007 and 2016, it can be observed that the total amounts paid in 2007 were 6,644,315,933.22 Euro, reaching 2009 $25,045,801,293.11$ Euro (+ $123.59 \%$ compared to 2008). The highest value was recorded in 2013 , the total payments made by the European Commission to the member countries of the European Union being 52,204,376,960.29 Euro. In 2016 these values began to fall, reaching in 2016 to $17,608,319,256.49$ Euro. Regarding the degree of absorption at EU28 level, a progressive increase is observed, from $1.97 \%$ in 2007, to $62.04 \%$ in 2013 and $98.2 \%$ in 2016. 
INTERNATIONAL JOURNAL OF ACADEMIC RESEARCH IN BUSINESS AND SOCIAL SCIENCES

Vol. 11, No. 3, 2021, E-ISSN: 2222-6990 @ 2021 HRMARS

Table 2. Share of decrease absorption and total amount

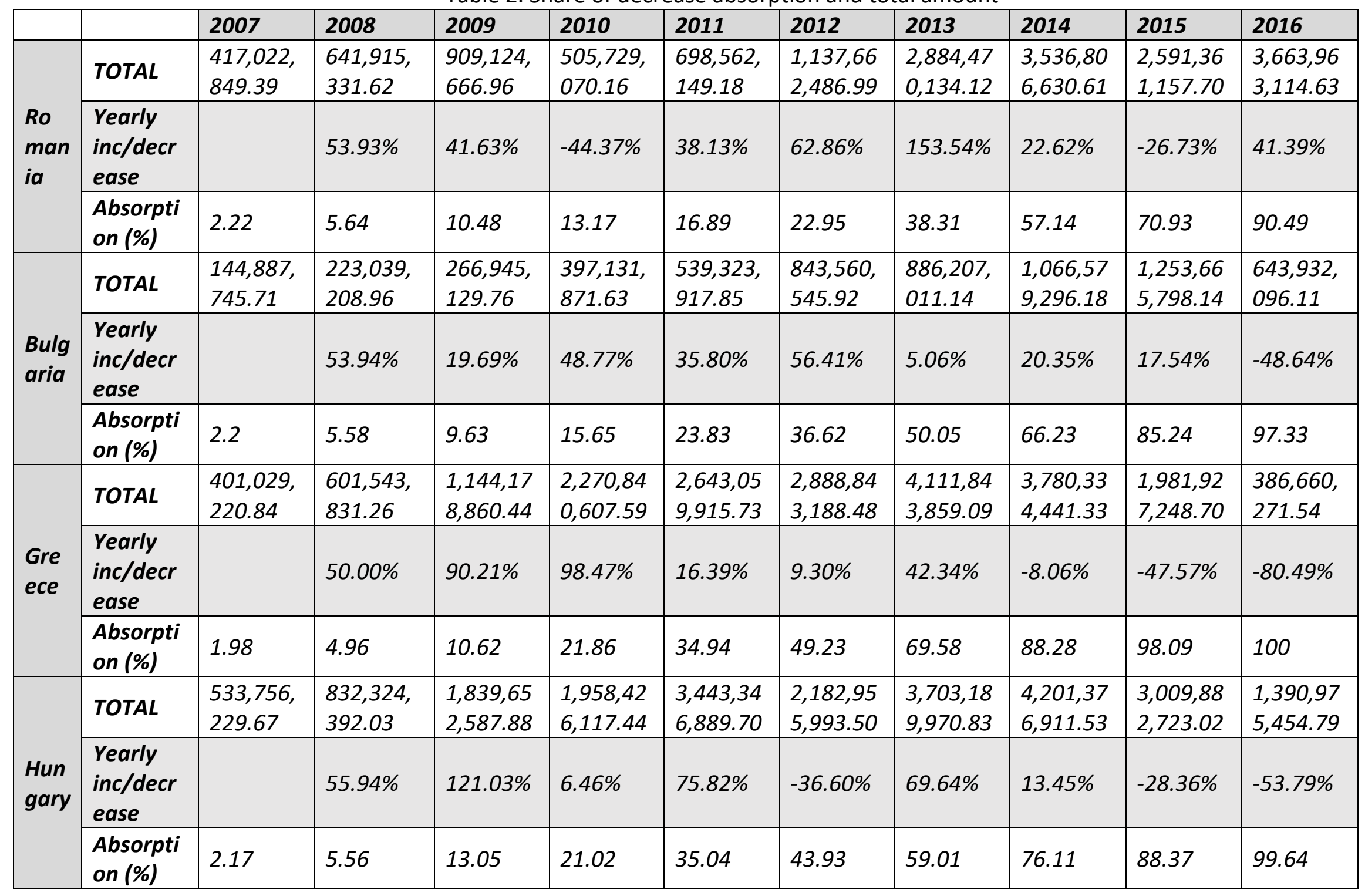


INTERNATIONAL JOURNAL OF ACADEMIC RESEARCH IN BUSINESS AND SOCIAL SCIENCES

Vol. 11, No. 3, 2021, E-ISSN: 2222-6990 @ 2021 HRMARS

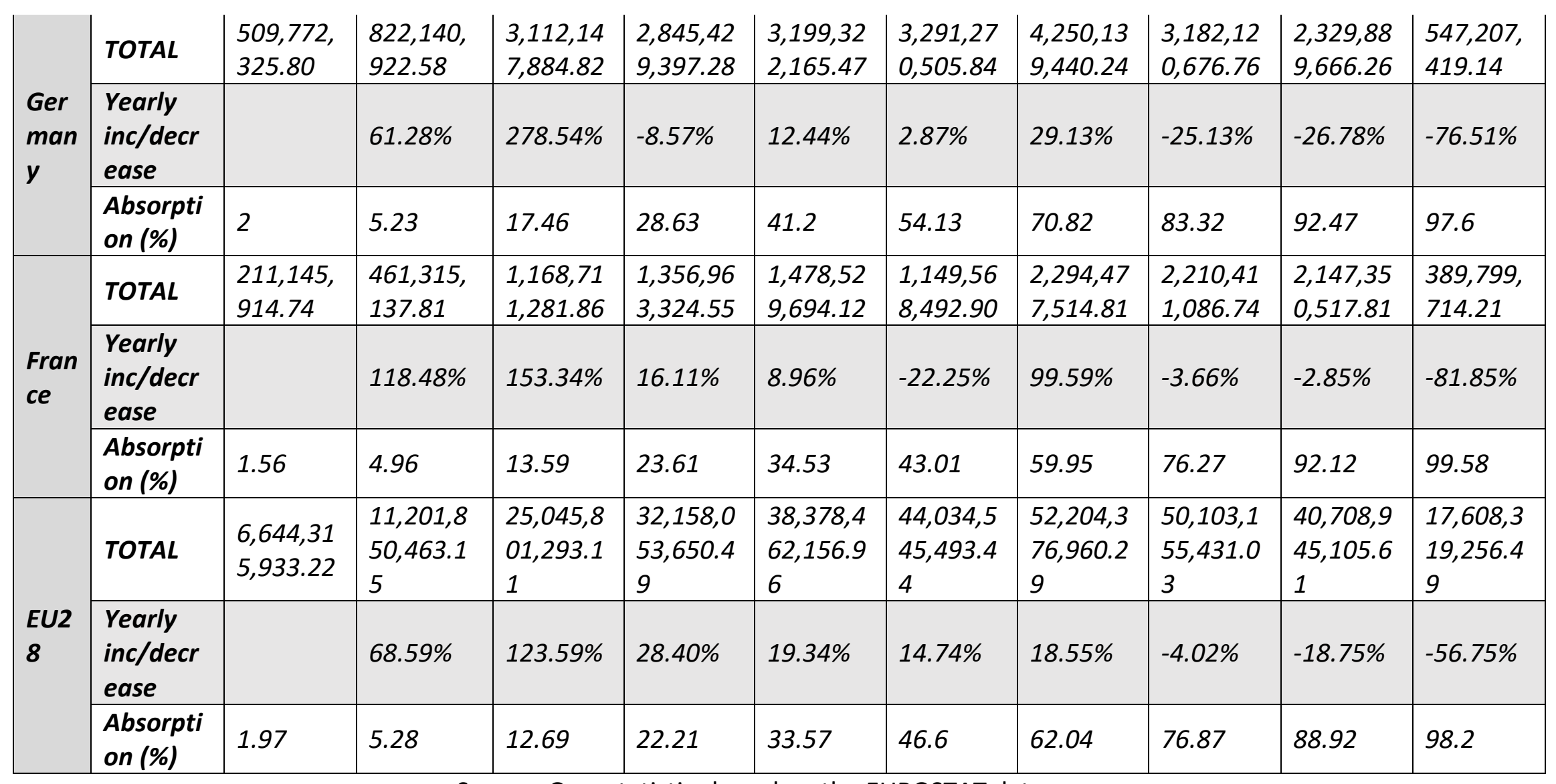

Source: Own statistics based on the EUROSTAT data 
If we previously analyzed for each country the payments made by the European Commission as well as the degree of absorption, in the graph below we can see a comparison of the amounts that were allocated during 2007-2016 to Romania, Bulgaria, Greece, Hungary, Germany and France. If in 2007, the highest revenues were directed to Hungary and Germany, in 2016 the European Commission reported the most payments to Romania, Germany receiving a much lower amount compared to previous years. If it is to analyze from the perspective of Romania it can be observed that, unlike the other countries, it received the lowest incomes in the period 2010-2011. The lowest payments were made by the European Commission to Bulgaria, in 2016 it received from the European Commission the highest amount compared to previous years.

Figure 1. Degree of absorption and total payments from European Union

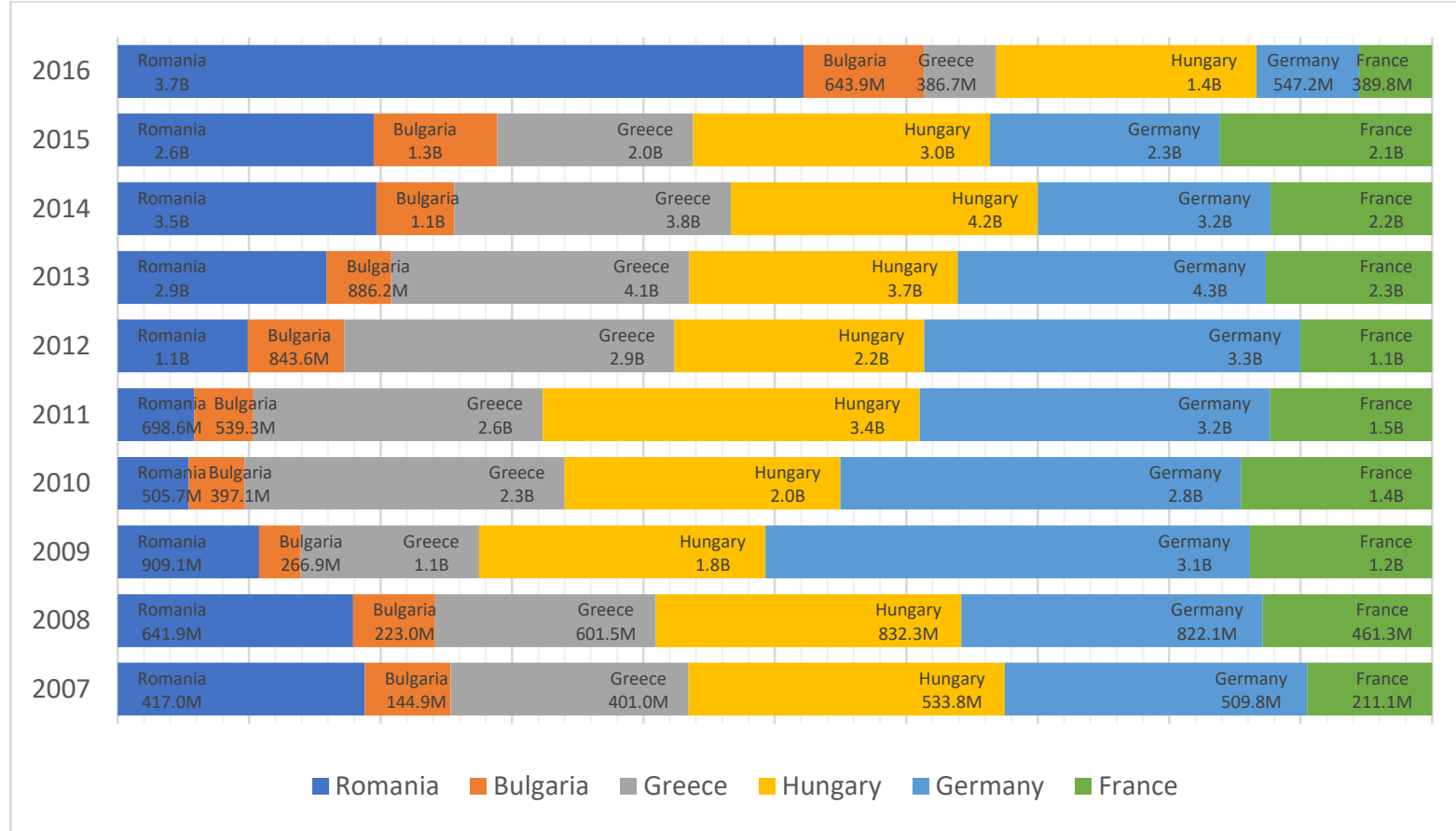

Source: Own documentation based on the EUROSTAT data

\section{Conclusions}

From the ones presented at the level of this qualitative research we could observe that the opinions of the experts, regarding the way the process of accessing the European tourism funds during the period 2007-2013, were divided. Thus, although they considered that during this period there was some increase, the impact of these projects financed from European funds was not seen as significant at the level of the development regions. In addition, the specialists considered that their distribution at the country level should be achieved in a balanced way, so that they are covered, both the developed areas and those that have not enjoyed a wider promotion so far. In order to observe the importance given by the experts to the projects financed from European tourism funds, they had to set out their views on how tourism would have evolved in the absence of the possibility of accessing European funds. The experts mentioned that the results of these projects contributed to a great extent to the development of the tourist activity from the destination level, however the growth registered could have been higher, if the activities carried out were better prioritized. Regarding the possibility of applying the planning activities process in general and the marketing planning in particular in the field of accessing the European funds in tourism, 
most experts considered this aspect as an opportunity, the techniques and tools existing in this field contributing, both to improving the access process, to increasing the degree of absorption. , as well as improving the communication process between the beneficiaries and the Managing Authority.

On the other hand, the experts considered that the revision of the Master Plan, the main national strategic document and the introduction of a section on marketing planning in the field of accessing European funds, is important. Moreover, specialists believe that web tools and technologies contribute to a great extent in facilitating the communication process, as they play an important role in transmitting and receiving information.

In conclusion, this research illustrates how European funds should be allocated in order to improve the results obtained. In this situation, the planning activities process in general and the marketing planning in particular can be implemented in the field of accessing European tourism funds. This can be an opportunity and the results that can be obtained can be viewed in a very short time. Moreover, the online marketing tools can help improve the communication process and increase absorption at the national level.

\section{References}

Bernini, C., Pellegrini, G. (2011), How are growth and productivity in private firms affected by public subsidy?, Evidence from a regional policy. Regional Science and Urban Economics, 41 pp. 253-265.

Bienkowska, E. (2017), Guide on EU funding for the tourism sector (2014-2020) - Study, https://op.europa.eu/en/publication-detail/-/publication/e0707433-aa5f-11e6-aab701aa75ed71a1.

Bronzini, R., Di Blasio, G. (2006), Evaluating the impact of investment incentives: the case of Italy's Law 488/1992, Journal of Urban Economics, 60 (2), pp. 327-349.

Carlucci, C., Pellegrini, G. (2004), Nonparametric analysis of the effects on employment of public subsidies to capital accumulation: the case of law 488/92 in Italy. Congress AIEL, Modena.

Catoiu, I. T. (2004), "Comportamentul consumatorului", (ed. a 2-a, revazuta și adaugita). București: Uranus.

Dębkowska, K., Szymańska, E. (2015), Potencjał turystyczny województwa podlaskiego na tle kraju i regionów zagranicznych [The tourism potential of the Podlaskie Voivodeship in comparison with other Voivodeships and foreign regions]. In: Szymańska E, editor. Wpływ projektów z zakresu turystyki i kultury na rozwój społeczno-gospodarczy regionu, Tom II, Białystok: Urząd Marszałkowski Województwa Podlaskiego, p. 56-68.

Denkowska, S. (2015), Wybrane metody oceny jakości dopasowania w Propensity Score Matching [Selected methods of assessing the quality of matching in Propensity Score Matching], Prace Naukowe Uniwersytetu Ekonomicznego we Wrocławiu, 384, pp. 6162.

Gabe, T. M., Kraybill, D. (2002), The effects of state economic development incentives on employment growth of establishments, Journal of Regional Science, 42 (4), pp. 703-730.

Gulc, A. (2015), Analysis of methodological approach to identify smart specialization on the example of Polish regions, Procedia - Social and Behavioral Sciences, 213, pp. 817-823

Keyuraphan, S., Thanarak, P., Ketjoy, N., Rakwichian, W. (2012), Subsidy schemes of renewable energy policy for electricity generation in Thailand, Procedia Engineering, pp. 440-448.

McDonald, M. (1998), "Marketing strategic". Bucuresti: Codecs. 
O'Sullivan, D. A. (2007), "Marketing Performance Measurement Ability and Firm Performance." Journal of Marketing (71), 79-83.

Paley, N. (2000). "Marketing strategy desktop guide." London: Hawksmere.

Panfiluk, E. (2015), Ocena efektów projektów z zakresu turystyki i kultury, realizowanych z Regionalnego Programu Operacyjnego Województwa Podlaskiego w latach 2007-2013 [Evaluation of the effects of projects in the field of tourism and culture, implemented with the Regional Operational Programme of Voivodeship Podlaskie in 2007-2013]. In: Szymańska E, editor. Wpływ projektów z zakresu turystyki i kultury na rozwój społecznogospodarczy regionu, Tom II, Białystok: Urząd Marszałkowski Województwa Podlaskiego; p. 178-245.

Panfiluk, E. (2012), Wyniki ekonomiczne działalności inwestycyjnej sektora publicznego w turystyce [Economic Results of Investment Activities of the Public Sector in Tourism], Zeszyty Naukowe.Uniwersytet Ekonomiczny w Poznaniu, 229 (2012), pp. 501-515.

Panfiluk, E. (2013), Analiza ekonomicznych wyników działalności inwestycyjnej w sektorze turystycznym, Studium przypadku województwa podlaskiego [The analysis of economic results of investment activity in tourist sector. Case study of Podlasie Voivodeship]. Prace Naukowe Uniwersytetu Ekonomicznego we Wrocławiu, 304, pp. 230-240

Panfiluk, E. (2013), Oddziaływanie instrumentów unijnych na działalność inwestycyjną w sektorze turystycznym [The Influence Of The EU Instruments On The Investment Activity On The Development Of Tourism], Zeszyty Naukowe Uniwersytetu Szczecińskiego. Ekonomiczne Problemy Usług, 2 (2), pp. 91-109

Panfiluk, E. (2015), Identyfikacja wskaźników i mierników oceny systemu zarządzania Europejskim Funduszem Rozwoju Regionalnego w sektorze turystycznym [Identification of the indicators and benchmarks of the assessment of the effects of management of the European Regional Development Fund in the tourism sector], Ekonomia i Zarządzanie, 7 (1) pp. 393-406.

Panfiluk, E. (2017), Analysis of the Effectiveness the European Regional Development Fund Disbursement for the Selected Tourism Services with the use of the Counterfactual Method, https://www.sciencedirect.com/science/article/pii/S1877705817312857.

Schubert, S., Brida, J. (2008), Dynamic effects of subsidizing the tourism sector, Tourism Economics, 14 (1), pp. 57-80.

Tołczyński, D. (2016), Development Policy of Warsaw Chopin Airport in the Light of the European Funds for 2014-2020, Procedia Engineering, 134, pp. 408-414

Verhoef, P. C. (2009), "Understanding the Marketing Department's Influence within the Firm." Journal of Marketing, 73(2), 14-37.

Wieseke, J. A. (2009), The Role of Leaders in Internal Marketing. Journal of Marketing, 73(2), 123-145. 